\title{
The Effort to Preserve the Art of Reyog Kendang as a Local Wisdom in Tulungagung Regency
}

\author{
Erika Novitasari ${ }^{1, *}$, Iim Siti Masyitoh ${ }^{2}$ \\ ${ }^{1,2}$ Universitas Pendidikan Indonesia Bandung, Indonesia \\ *Corresponding author.Email: erikanovitasari@upi.edu
}

\begin{abstract}
The flow of globalization brings many influences in various dimensions of life. One of them is in terms of culture. In the midst of the rise of foreign cultures that enter, as good citizens must always maintain the existence of our own regional culture. Art is the result of human culture that must be studied, preserved, published and developed to elevate the culture of a particular area. Art must be preserved so as not to perish with the changing times. Art must be published and developed so that it is known by many people and can compete with others. In this regard, the authors are interested in conducting research regarding the preservation of reyog kendang art as local wisdom in Tulungagung district. The approach used in this research is using a qualitative approach. The method used is a case study. Data collection techniques used are observation, in-depth interviews and documentation studies. The analysis used is by using data triangulation techniques. The results of the research are that there are several ways to preserve the art of reyog drums, namely: through extracurricular activities at school, through art performances to commemorate national holidays, through art performances to commemorate traditional ceremonies in the community, through implementation in various art forms such as batik motifs clothing accessories, souvenirs and other forms. The conclusion of the research is that there is a continuous effort in an effort to preserve this art.
\end{abstract}

Keywords: Conservation, Local Wisdom, Reyog Kendang.

\section{INTRODUCTION}

The flow of globalization brings many influences in various dimensions of life. One of them is in terms of culture. In the midst of the rise of foreign cultures that enter, as good citizens must always maintain the existence of our own regional culture. Art is the result of human culture that must be studied, preserved, published and developed to elevate the culture of a particular area. Art must be preserved so as not to perish with the changing times. Art must be published and developed so that it is known by many people and can compete with others.

The openness of the younger generation in Indonesia to foreign cultures is shown in the results of the research and development "Kompas" in 2013 which showed that the younger generation was more familiar with modern arts by $84 \%$ and traditional arts by $15.7 \%$ and the interest of the younger generation in modern arts by $56.2 \%$ and the arts. traditional $43.1 \%$ (Litbang Kompas 20 December 2013 Expressing Yourself With Art. Kompas, P39) [1]. From the results of the survey, it can be seen that the sense of nationalism of Indonesia's young generation is decreasing.

In the period 2007-2012, Malaysia has claimed seven cultures belonging to Indonesia and recognized them as their cultural heritage. The first cultural claim made by Malaysia against indigenous Indonesian culture was in
November 2007 against the art of "Reog Ponorogo". Furthermore, the claim continued in December 2008 namely the claim to the song "Rasa Sayange" from the Maluku Islands. The next list of claims was in January 2009 on batik culture, then Pendet Dance was also claimed by one of the private party advertisements that appeared on tourism promos on television on the Discovery Channel program entitled Enigmatic Malaysia in August 2009.2 Furthermore, angklung musical instruments and ensembles in March 2010 and claims Malaysia for the tor-tor dance and Gondang Sambilan which are native arts from North Sumatra (Antaranews: 2012) [2].

With the problems that are so complex, then as the next generation of course must be able to maintain and preserve the existing culture. This is because so that the problems that have occurred do not recur. And to increase the sense of nationalism as the next generation of the nation.

\section{THEORETICAL REVIEW \\ 2.1. Conservation}

Conservation is essentially an effort to maintain that a cultural resource remains in the context of the system so that it can function actively or by the community. In order to survive, cultural resources that still exist in the context of the system may have to be reused or recycled. 
Talcott Parson [3] provides signs that are raised through his theory entitled social system. In this theory he states that if a society wants to exist with its identity, it must have the ability to maintain its identity. So one way to maintain their identity is by preserving their own regional culture which is of course the identity of the community itself.

In short, conservation will be sustainable if it is based on internal strength, local strength, and self-reliance. Therefore, it is necessary to move people, observers, lovers and supporters from various walks of life. For this reason, it is necessary to develop a strong motivation to be moved to participate in carrying out conservation, including:

a. Motivation to maintain, maintain and pass on the cultural heritage inherited from previous generations

b. Motivation to increase the knowledge and love of the next generation of the nation towards the historical values of the nation's personality from time to time through the inheritance of cultural treasures and real cultural values that can be seen, remembered and lived

c. Motivation to ensure the realization of diversity or variation in the cultural environment

d. Economic motivation that believes that the value of local culture will increase if it is well maintained so that it has commercial value to improve the welfare of the owner

e. Symbolic motivation that believes that local culture is a manifestation of the identity of a group or community so that it can develop a strong sense of pride, self-esteem and self-confidence.

Many of the lovers and observers of cultural heritage believe that cultural resources are not only heritage, but rather are heritage for the nation. [3]. This means that cultural resources have the power that can be used to help and protect this nation in treading the path to the future. As an heirloom, the cultural heritage must be maintained so that its strength is not lost and can be passed on to the next generation without reducing its value.

\subsection{Local Wisdom}

A local wisdom has many values that can be taken and applied to everyday life. There is a close relationship between the local wisdom of an area in shaping one's character. In carrying out each social process, it can be based on the value of local wisdom that exists in the area as the foundation. In this regard, character is a collection of values that lead to a system which is the basis for thinking, behaving and behaving [4].

Some of the characteristics of local wisdom are:

a. Have the ability to survive in the presence of a new culture

b. Have the ability to adapt to a new culture

c. Have the ability to be able to blend in with new cultures that are included in the original culture d. Have the ability to be able to control yourself in the presence of a new culture

e. Have the ability to be able to give direction with existing developments [5].

Local wisdom is a characteristic of an area. It is this characteristic that distinguishes one place from another. The form of a lokan wisdom varies. The classification of local wisdom is divided into 3 , namely:

a. Ideology and tradition. This type of group means that a local wisdom is in the form of thinking that tends to an understanding in dealing with social life

b. Relationships and social networks. This type of grouping means that an individual who is bound by social ties in various social groups.

c. local institutions. This type of group means that an organization that has a function for the benefit of a community group [6].

\subsection{Reyog Kendang}

The emergence of this art originated from a legend that tells of the King of Bugis who will propose to the princess of the kingdom of Kediri named Dewi Kilisuci. Several soldiers were sent by the Bugis King to propose to Dewi Kulisuci. The soldiers encountered obstacles in Madiun so they took the wrong direction through Ponorogo, Trenggalek, Tulungagung and arrived at Kediri. Arriving in Kediri the envoys said that the Princess Dewi Kilisuci would be proposed by the King of Bugis. But the proposal was politely rejected by the princess with several conditions. On the way back to the Bugis King, some of the soldiers asked for the help of the people of Tulungagung to translate the conditions given by Dewi Kilisuci.

The six conditions are the first, namely "the eye of a tukung cock as big as a slanted fly that is hung in the penceng hut". The meaning of that expression is a gong that is hung in its ganor, which is one of the musical accompaniment instruments in the performance. The second condition is "a flute of a rice tree as big as a coconut trunk". The meaning of the expression is in the form of a selompret musical instrument that accompanies the performance. The third condition is "jerky tuma sak tetelan pulut". The meaning of the expression is the kenong musical instrument, which is the accompaniment instrument in reyog kendang. The fourth condition is "ati tengu as big as a bolster". The meaning of this expression is iker which is a headband worn by reyog kendang dancers. The fifth requirement is "six roof honey lance". The meaning of the expression is "dhodog" (drum) which is carried by each dancer. The sixth requirement is "gold binggel that can ring itself". The meaning of the expression is "gongseng" which is a piece of equipment worn on the dancer's feet [7].

In connection with the above, in every performance of reyog kendang there are several things that must be present, namely, a gong which is a kempul which is attached to the ganor, slompret or trumpet, dhodhong is a small drum carried by each dancer, a headband or iker, 
kenong as an instrument, and gongseng. is a binggel used on the feet of reyog kendang players [8]. Based on the above, even though there is development in this art, it is not permissible to leave 6 things as above. Because the main value in art is in the above. Every movement in the reyog drum dance has its own characteristics and uniqueness. Each geran has a deep meaning [9].

In the art of reyog drums, there are various kinds of moral values that can be taken. These moral values are reflected in every presentation in this reyog drum art. This moral value can shape the character of each performer of this art. Not only that, that trainers and connoisseurs of reyog kendang art performances can also take values from this reyog kendang art. As expressed [10] that in the art of reyog kendang there are values of tolerance, discipline, responsibility, cooperation.

\section{METHOD}

This study uses a qualitative approach, the data used are in the form of data (words, pictures, behavior), the data does not use numbers or statistical figures, but in qualitative form. The same thing is also supported by [11] that qualitative research can get answers from participants in the form of data in the form of words (interviews), pictures (photos). It is also supported by [12] that qualitative research is a researcher who focuses on exploration, description, and sometimes deriving and constructing a theory using qualitative data.

The method used is a case study because it is a type of qualitative method that raises the characteristics of a problem. Another reason for using this method is because this problem occurs in the real world, at a certain time and place, namely in Tulungagung Regency. As stated by Yin [13] that the case study research method as an empirical inquiry that investigates a contemporary phenomenon within its real-life context; when the boundaries between phenomenon and context are not clearly evident; and in which multiple sources of evidence are used.

Data collection techniques in this study are in the form of observation, interviews, document studies. The data analysis technique used is as described by Miles and Huberman [14] that data analysis takes three main steps, namely data reduction, data display or data presentation, and verification and/or data reduction.

The participants in this study were, first, the Reyog Kendang Artist. Digging up data from reyog drum artists is very necessary. Because the artists are the main informants who can answer the research problems proposed.

The second is the Tulungagung Regency Youth and Sports Tourism Office. The reason for choosing the related department is because it can be used as a secondary data source to answer the problem formulation contained in this study.
The third is the general public. In choosing this participant, it was to explore how far the community's role was in maintaining the value of the law through the art of Reyog Kendang.

\section{RESULT AND DISCUSSION}

The results of the research are that there are several ways to preserve the art of reyog kendang, namely: firstthrough extracurricular activities at school, (extracurricular activities for all public schools in Tulungagung district), the second is through art performances in commemorating national holidays, (in commemorating national holidays such as in celebration of the Republic of Indonesia's Anniversary), third, namely through art performances in commemorating the ceremony. The fourth is through the implementation in various forms of art such as batik motifs, clothing accessories, souvenirs and other forms.

As an extracurricular activity at school, this reyog drum art is always played in every public school in Tulungagung district. The Reog Kendang Extracurricular is held once a week. To be able to take part in these extracurricular activities, each student must register when there is a recruitment process for Reog Kendang extracurricular members which is held at the beginning of each school year. The way in which students are recruited in schools to become members of the Reog Kendang extracurricular is based on the students' personal awareness, not under coercion from any party.

In this regard, if students take part in extracurricular activities according to their awareness, students will automatically be active in participating in these activities considering that there are many other extracurricular activities that can be followed besides reog kendang extracurricular. This thought is in accordance with the results of interviews conducted with students participating in Reog Kendang extracurricular activities. The students admitted that they were actively involved in Reog Kendang extracurricular activities because from the beginning they intended to take part in these activities, either with the aim of developing talents and interests or because of the students' desire to participate in preserving the traditional art of Reog Kendang.

The Reog Kendang extracurricular held by every school is not solely to preserve the Reog Kendang art, but also to develop the talents, interests or potential of students. However, through the reog kendang extracurricular, the school wants to instill the character of love for the homeland in students, increasing students' self-awareness of local culture. In addition, the school also makes Reog Kendang extracurricular as a means for the manifestation of Javanese culture to fulfill the element of beauty alone but to convey noble values to the community.

In relation to the participation of students in Reog Kendang extracurricular activities, the data obtained from 
interviews showed that the reason for students' participation in Reog Kendang extracurricular activities was because they wanted to develop talents, interests and potentials that existed in students. Basically, students who take Reyog Kendang extracurricular already know their talents. Most of the students stated that since elementary school the students had participated in extracurricular activities so that in the end the talents they had wanted to be further developed by participating in the same extracurricular activities at the junior high school level. In addition to developing the talents, interests or potential of students in the arts.

The participation of students in Reog Kendang extracurricular activities is inseparable from the support of their parents. Based on the results of interviews with students and teachers of Reog Kendang extracurricular coaches, it was found that all parents supported students' involvement in Reog Kendang activities. This is because basically parents of students already know the talents and potential of their children. So that parents always support students' participation in Reog Kendang extracurricular activities. Some students also stated that parents provide support because parents want their children to participate in preserving regional culture or traditional culture so that later it can be passed on to grandchildren or the next generation.

The next form of preservation is through art performances in commemorating national holidays (in commemorating national holidays such as in the celebration of the Republic of Indonesia's Anniversary), and also through art performances in commemorating traditional ceremonies in the community (in commemorating village clean ceremonies), as well as through implementation in various forms. arts such as batik motifs, clothing accessories, souvenirs and other forms.

\section{CONCLUSION}

Based on the results of the research above, it can be found that conservation will be sustainable if it is based on internal strength, local strength, and self-help power. Therefore, it is necessary to move people, observers, lovers and supporters from various walks of life. For this reason, it is necessary to develop a strong motivation to be moved to participate in carrying out conservation. This is done so that this art can survive in the midst of the rise of other foreign cultures.

\section{REFERENCES}

[1] Compass Research and Development, 2013, Expressing Yourself With Art, Kompas, pp. 39

[2] Antaranews.com, 2012, Malaysia claims 7 Indonesian cultures in http://www.antaranews.com/berita/317054/20072012-malaysia-claim-seven-culture-Indonesia
[3] Gustianingrum. Pratiwi. W, 2016, Efforts to Preserve Regional Cultural Values in Formation of National Character, Bandung: UPI Thesis

[4] Komalasari \& Saripudin, 2017, Character Education (Concepts and Applications of Living Value Education). Bandung: PT Refika Aditama

[5] Amir \& Ridho, 2021, Consolidating the Value of Nationalism through Extracurricular Activities for Asga Mandiri Vocational High School Students in Medan. Genta Mulia ISSN: 23016671. Volume XII No. 1, January 2021. F - F: 252-262

[6] Rahmatih, Maulyda, Syazali, 2020, Reflection on the Value of Local Wisdom in Elementary School Science Learning. Journal. MIPA Incandescent, 15(2), 151-156. ISSN 1907-1744 (Print). Doi: 10.29303/Jpm.V15i2.1663 ISSN 2460-1500 (Online). PP: 151

[7] Hayuhantika. Rahayu, 2019, Exploration of Mathematical Ideas in Art Reyog Tulungagung. Prismatics: Journal of Mathematics Education and 2(1), 5esearch, 5-15. https://scholar.google.com/scholar

[8] Shanti, 2017, Reog Kendang Tulungagung Art as an Inspiration for the Development of Batik Motifs in Tulungagung Regency. National Seminar on Art and Design: "Building a Tradition of Innovation Through Research Based on Art and Design Practices" FBS Unesa, 28 October 2017, 170-198. https://proceedings.sendesunesa.net/tr/publication s/196079/

[9] Febriansyah, Wedi, Husna, 2020, Development of the Reog Kendang Dance Instructional Local Content Curriculum at Pucangan 2 State Elementary School. Jinotep (Journal of Learning Technology Innovation) Studies and Research in Learning Technology, 6(2), 69-82. https://scholar.google.com/scholar

[10] Nugraheni, Wiga, 2018, Implanting Moral Values Through Reog Kendang Art for Students in Tulungagung Regency. Journal of art and arts education, 16(2), 155-169. DOI: https://doi.org/10.21831/imaji.v16i2.22744

[11] Creswell, John W, 2015, Qualitative Research \& Research Design. Yogyakarta: Student Library

[12] Johnson, Burke \& Christensen, Larry, 2014, Educational Research: Quantitative, Qualiative, And Mixed Aproaches. California: SAGE Publications, Inc. ISBN 978-1-4522-4440-2

[13] Muchtar, Suwarma. (2015). Qualitative Research Basis. Bandung: Independent Library Degree.

[14] Ali, Mohammed. 2019. Research Methods In Sustainability Education. Bandung: University of Education Indonesia Press 